\title{
TARI GAJA MENUNGGANG MASYARAKAT SUKU SAWANG BELITUNG: ANALISIS TANDA DAN MAKNA
}

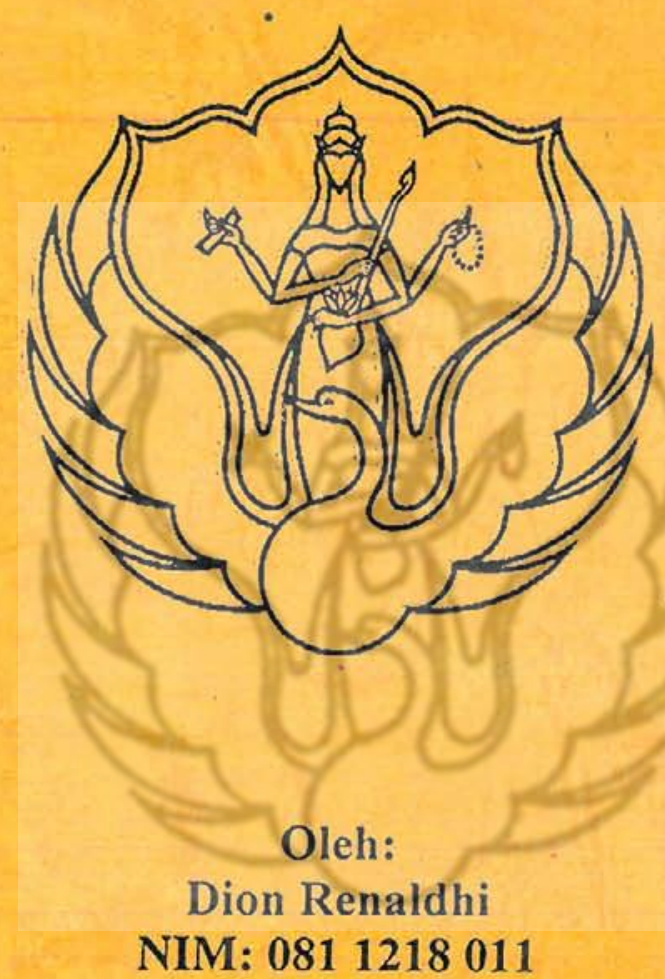

TUGAS AKHIR PROGRAM STUDI S-1 SENI TARI JURUSAN TARI FAKULTAS SENI PERTUNJUKAN INSTITUT SENI INDONESIA YOGYAKARTA GENAP 2011/2012 
TARI $G A J A M E N U N G G A N G$ MASYARAKAT SUKU SAWANG BELITUNG: ANALISIS TANDA DAN MAKNA
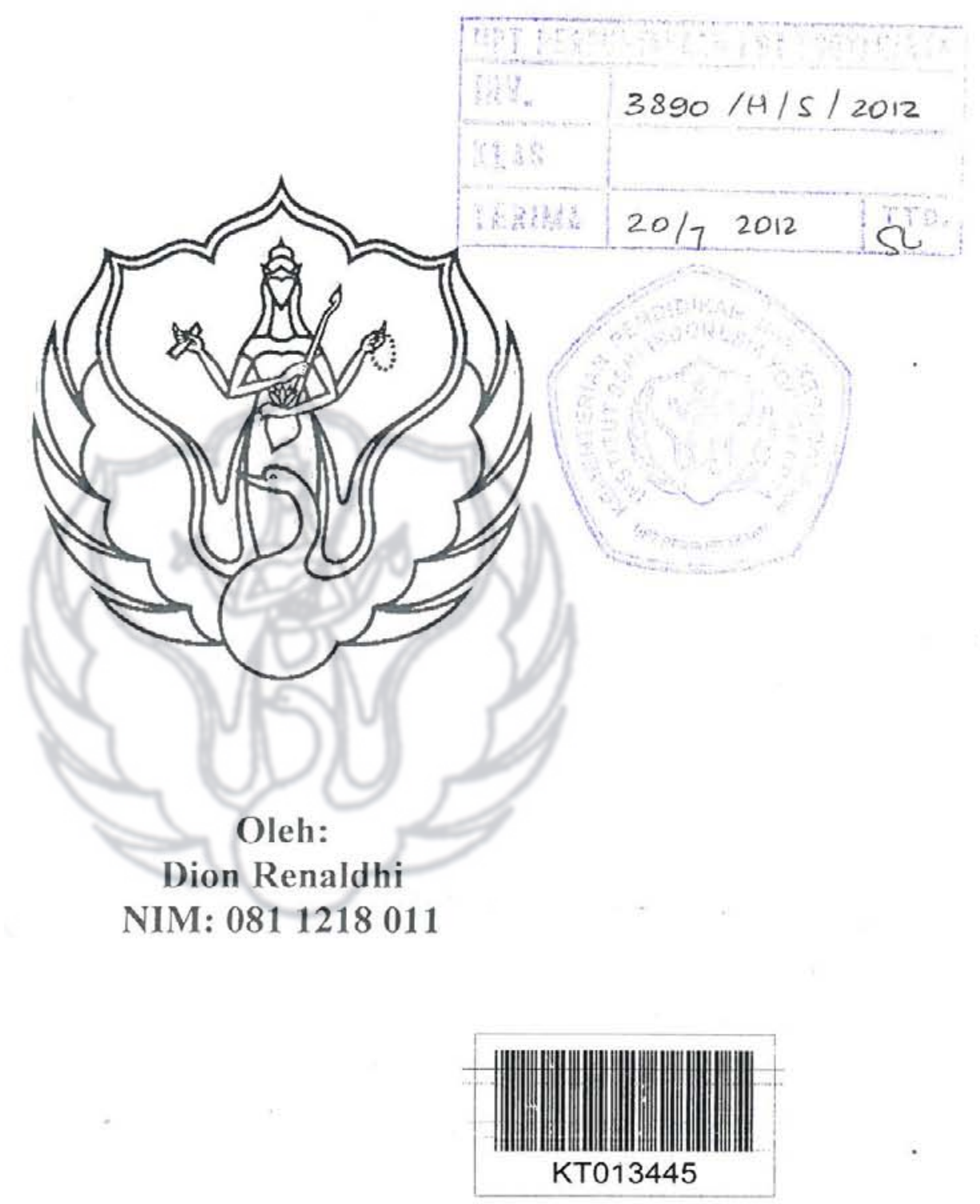

TUGAS AKHIR PROGRAM STUDI S-1 SENI TARI JURUSAN TARI FAKULTAS SENI PERTUNJUKAN INSTITUT SENI INDONESIA YOGYAKARTA GENAP 2011/2012 


\section{TARI GAJA MENUNGGANG MASYARAKAT SUKU SAWANG BELITUNG: ANALISIS TANDA DAN MAKNA}
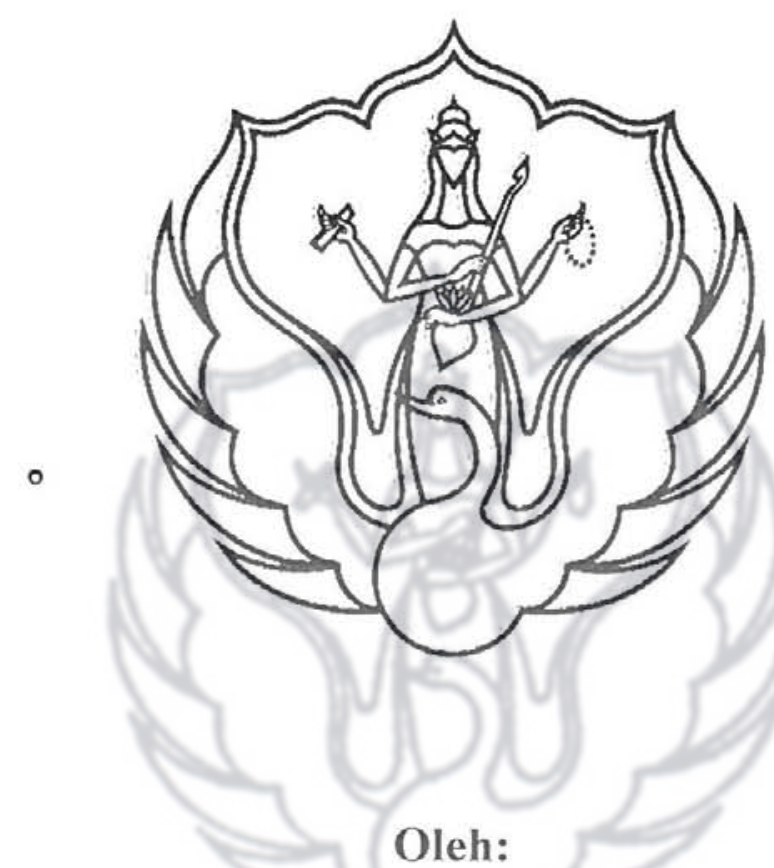

Dion Renaldhi

NIM: 0811218011

TUGAS AKHIR PROGRAM STUDI S-1 SENI TARI JURUSAN TARI FAKULTAS SENI PERTUNJUKAN INSTITUT SENI INDONESIA YOGYAKARTA GENAP 2011/2012 


\section{TARI GAJA MENUNGGANG MASYARAKAT SUKU SAWANG BELITUNG: ANALISIS TANDA DAN MAKNA}

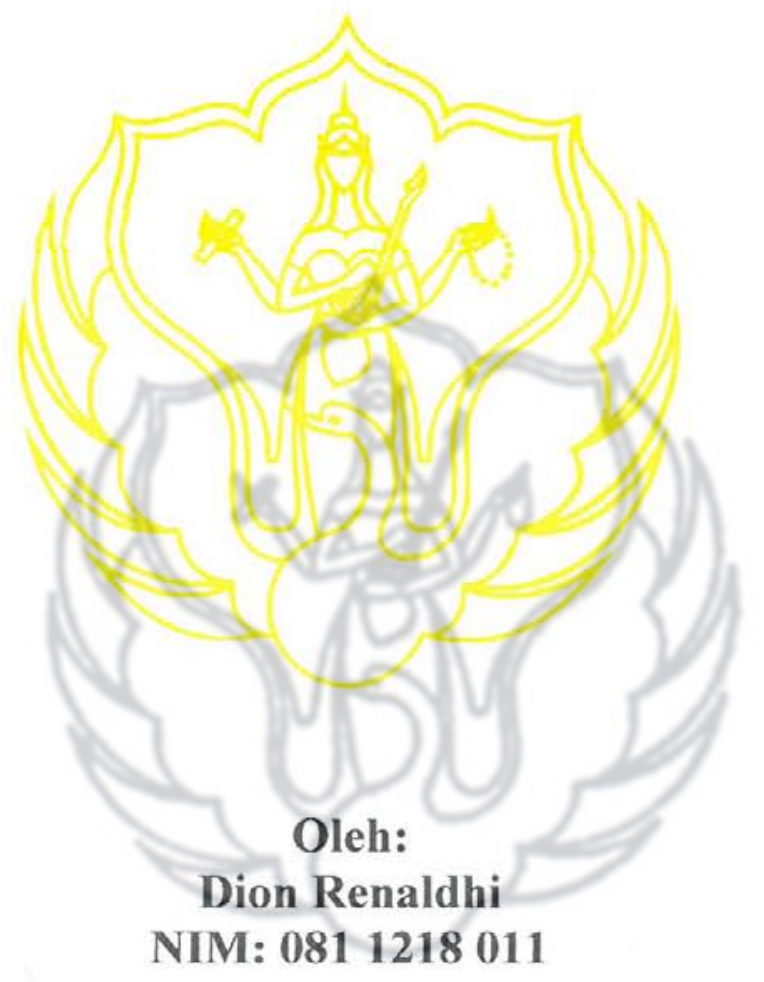

Tugas Akhir Ini Diajukan Kepada Dewan Penguji Fakultas Seni Pertunjukan Institut Seni Indonesia Yogyakarta Sebagai Salah Satu Syarat

Untuk Mengakhiri Jenjang Studi Sarjana S-1

Dalam Bidang Seni Tari

Genap 2011/2012 
Tugas akhir ini telah diterima dan disetujui Dewan Penguji

Fakultas Seni Pertunjukan

Institut Seni Indonesia Yogyakarta

Yogyakarta, 28 Juni 2012
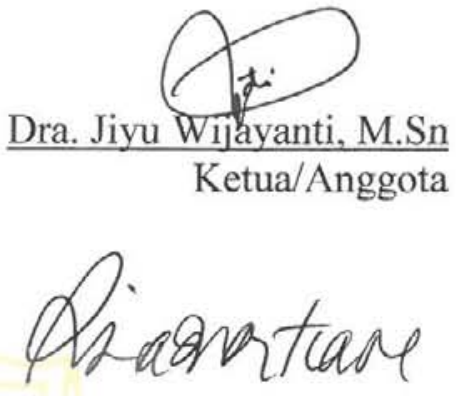

Dr. Rina Martiara, M.Hum. Pembimbing I/Arggota

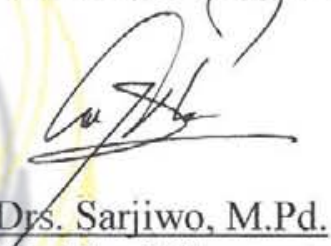
Pembimbing II/Anggota

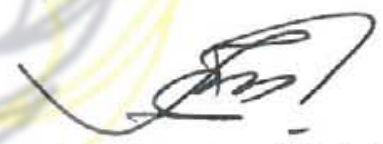

Dr. Bambang Pudjasworo, M. Hum. Penguji Ahli/Anggota

\section{Mengetâtiui}

Dekan Fakultas Seni Pertunjukan

Institut Seni Indonesia Yogyakarta

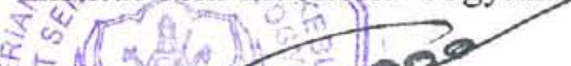

Prof. Or I WayanDana, S.S.T., M.Hum.

NIP. 195603081979031001 


\section{PERNYATAAN}

Dengan ini saya menyatakan bahwa dalam skripsi ini tidak terdapat karya yang pernah diajukan untuk memperoleh gelar kesarjanaan di suatu Perguruan Tinggi, dan sepanjang sepengetahuan saya juga tidak terdapat karya atau pendapat yang pernah ditulis atau diterbitkan oleh orang lain, kecuali secara tertulis diacu dalam naskah ini dan disebutkan dalam daftar pustaka. 


\title{
RINGKASAN
}

\section{TARI GAJA MENUNGGANG MASYARAKAT SUKU SAWANG BELITUNG: ANALISIS TANDA DAN MAKNA}

\author{
Oleh: Dion Renaldhi
}

Tulisan ini menganalisis tanda dan makna yang terkandung dalam tari Gaja Menunggang sebagai hasil karya dari masyarakat suku Sawang. Sesuai dengan pandangan Peirce, tanda adalah sesuatu yang mewakili sesuatu yang lain untuk sesuatu dengan kapasitas tertentu. Jakob Sumardjo juga mengatakan bahwa dalam tari tradisi yang hidup dan berkembang di lingkungan masyarakat primordial, keberadaan tanda-tanda presentasional tidak lagi berada pada kisaran indah dan menyenangkan, melainkan sebagai suatu pernyataan atas kepercayaan, makna, dan nilai yang berlaku dalam lingkungan masyarakat tersebut serta berkaitan dengan sesuatu yang transenden. Dengan kata lain, semua penandaan di dalam karya seni tersebut pasti memiliki maksud atau tujuan tertentu, yang dalam istilah Pierce disebut sebagai motif dalam penanda.

Tari Gaja Menunggang adalah tari dengan latar belakang cerita Gaja Menunggang, yang mengisahkan tentang seorang pemuda sakti yang berpindah alam demi menjaga hewan Gaja Mina agar tidak mengganggu ketentraman di laut. Walaupun tari Gaja Menunggang ini berlatar belakang cerita tersebut, namun beberapa elemennya seperti gerak, busana, dan syair lagu memiliki temanya masing-masing. Tari Gaja Menunggang juga tergolong sekuler, walaupun cerita yang melatarbelakangi tari ini sangat berkaitan dengan kepercayaan dari masyarakat suku Sawang. Gerak tari Gaja Menunggang bercerita tentang aktivitas masyarakat suku Sawang di laut, busana menjadi penggambaran busana keseharian suku Sawang, dan syair lagu merupakan pantun dengan tema nasehat, petuah, keluh kesah, dan cerita nostalgia individu. Tanda-tanda yang dianalisis dari tari Gaja Menunggang diambil dari beberapa elemen, yaitu cerita Gaja Menunggang, mitos Gaja Mina, gerak, syair pantun, dan busana. Pemilihan atas elemen yang akan dianalisis berdasarkan kapasitas dan kemampuan analisis, serta keterbatasan waktu.

Tari Gaja Menunggang merupakan bentuk ekspresi dari pola hidup yang terdapat dalam masyarakat suku Sawang Belitung, seperti kedudukan serta peran perempuan dan laki-laki dalam sebuah lingkup sosial tertentu, peran dan tanggung jawab mereka dalam sebuah keluarga dan masyarakat, kepribadian-kepribadian yang masyarakat miliki dalam menjalani hidup, serta cara pengungkapan kepercayaan mereka atas semua fenomena yang terjadi di sekeliling mereka. Tari Gaja Menunggang juga menjadi sebuah penciri bagi masyarakat suku Sawang Belitung sebagai suku yang beibukan laut.

Kata kunci: tari Gaja Menunggang, suku Sawang, tanda, makna. 


\section{KATA PENGANTAR}

Puji syukur ke hadirat Allah Yang Esa yang dengan kuasaNya memberikan petunjuk dan semua berkah atas selesainya tulisan "Tari Gaja Menunggang Masyarakat Suku Sawang Belitung: Analisis Tanda dan Makna” ini sebagai salah satu syarat kelulusan dari studi Strata-1 di Program Studi Pengkajian Seni Tari, Jurusan Tari, Fakultas Seni Pertunjukan, Institut Seni Indonesia Yogyakarta. Sebuah berkah tersendiri ketika berhasil menyelesaikan studi tepat selama 4 tahun, karena semua yang dikeluarkan terbayarkan sudah. Selesainya skripsi ini tidak terlepas dari bantuan berbagai pihak, sehingga sudah selayaknya apabila ucapan terima kasih disampaikan kepada:

1. Ibu Dr. Dra. Rina Martiara, M. Hum., selaku Pembimbing I dalam tugas akhir ini. Beliau bukan hanya sebagai pembimbing, tapi juga sebagai ibu, sahabat, dan sumber inspirasi dalam penulisan tugas akhir ini. Orang yang selalu membimbing dan mengarahkan dengan penuh kesabaran dan keihklasan dari awal hingga selesai.

2. Bapak Drs. Sarjiwo, M. Pd., selaku Pembimbing II yang telah meluangkan banyak waktunya demi konsultasi-konsultasi demi mencapai sebuah tulisan yang layak dinyatakan lulus sebagai skripsi. Sebuah keberuntungan yang sangat besar saat beliau menjadi salah satu pembimbing dari tulisan ini.

3. Bapak Prof. Dr. I Wayan Dana, S.S.T., M. Hum., selaku Dosen Wali atau Pembimbing Studi yang selalu memberikan dukungan moril dari pertama menjadi wali hingga studi di ISI Yogyakarta ini selesai.

4. Bapak Idris Said dan Bapak Salim Y.A.H., selaku narasumber yang rela meluangkan waktunya demi menjawab keingintahuan demi tercapainya tulisan ini.

5. Segenap Dosen Jurusan Tari ISI Yogyakarta, terutama Bapak Dr. Hendro Martono, M. Sn., sebagai salah satu dosen yang selalu mendekatkan dirinya dengan mahasiswa yang telah memberikan beberapa referensi yang sangat berguna, serta nasihat-nasihatnya selama ini. 
6. Seluruh staf Perpustakaan ISI Yogyakarta yang membantu dalam penyediaan buku-buku referensi.

7. Ibuku Eny Mariyani M, S. Pd., Ayahku Iwan Yuliardi, kakekku Usman dan Nurdin, serta nenekku Dalniah dan Syamsiah, orang-orang yang menyayangi dan memberikan semua dukungan, semangat, dan pengorbanannya dengan kesabaran dan pengertian selama studi di Jurusan Tari ISI Yogyakarta ini ditempuh.

8. Darta Meilando dan Ayudha Luthfiyanti, sahabat yang telah memberikan bantuan dan semangat selama proses tugas akhir ini.

9. Semua pihak yang telah membantu dan mendukung dalam pengerjaan tugas akhir ini, yang tidak dapat disebutkan satu persatu.

Skripsi ini memang jauh dari sempurna, dan banyak hal yang harus diperbaiki. Saran, kritik, dan masukan sangat dibutuhkan demi meningkatkan mutu dari penelitian ini agar lebih baik di kemudian hari. Semoga tulisan ini bermanfaat bagi semua yang membaca.

Yogyakarta, 28 Juni 2012

Peneliti

\section{Dion Renaldhi}




\section{DAFTAR ISI}

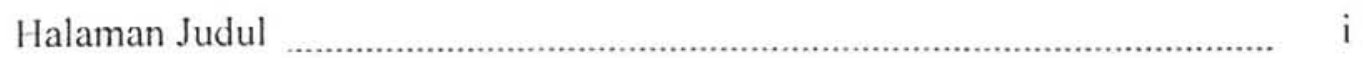

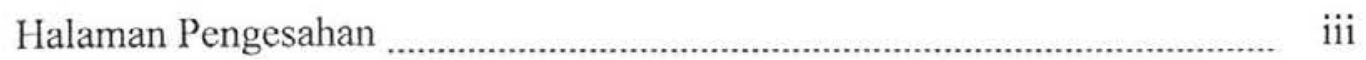

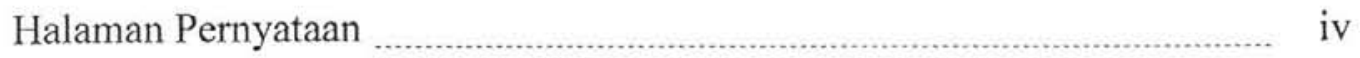

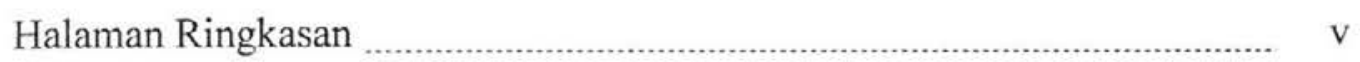

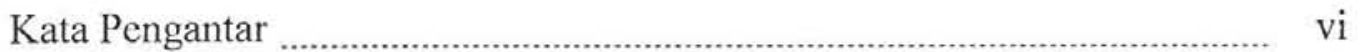

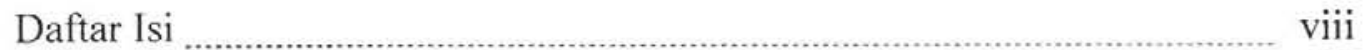

Daftar Gambar

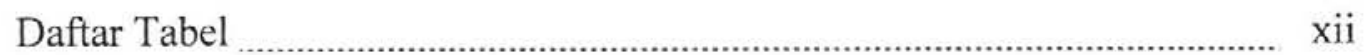

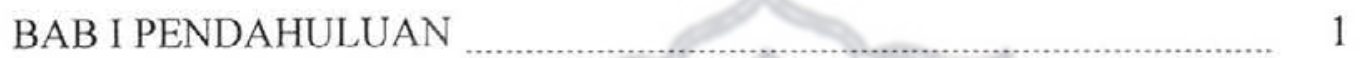

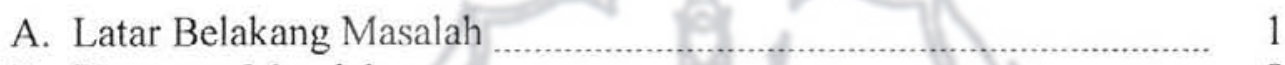

B. Rumusan Masalah ..................................................................... 8

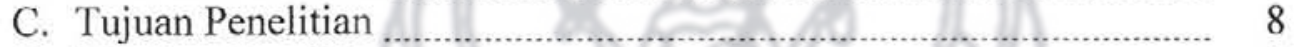

D. Manfaat Penelitian _...

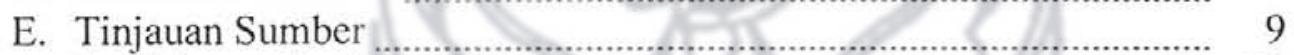

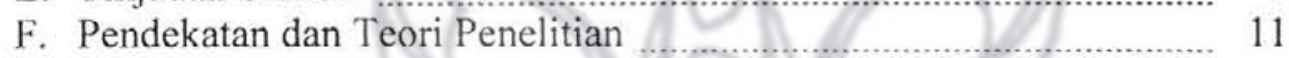

1. Tari Gaja Menunggang, first order semiotics ............................. 13

2. Tari Gaja Menunggang, second order semiotics _.................... 14

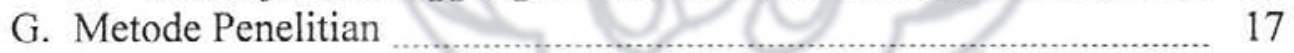

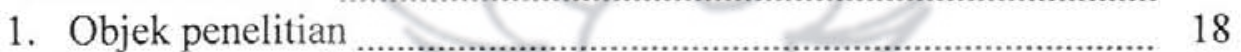

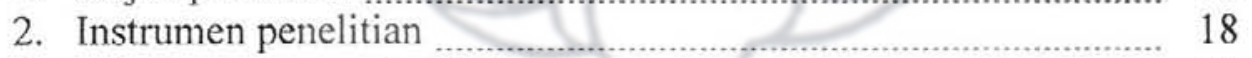

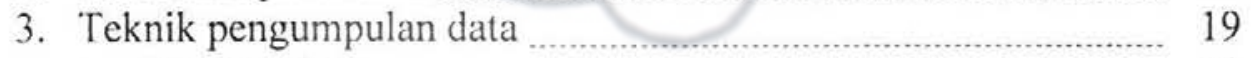

a. Studi pustaka ....................................................................... 19

b. Observasi 19

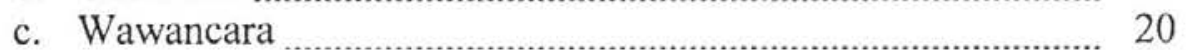

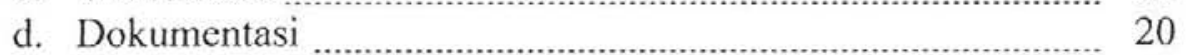

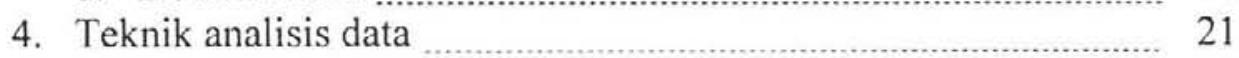

5. Teknik penulisan laporan akhir ..................................................... 21

\section{BAB II KONDISI SOSIAL BUDAYA MASYARAKAT SUKU}

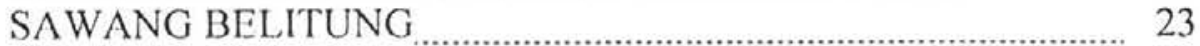

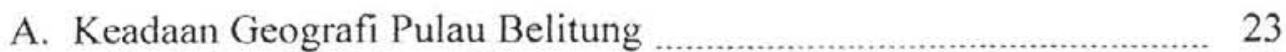

B. Sejarah dan Kehidupan Masyarakat Suku Sawang Belitung ............. 28

C. Sistem Religi yang Berkembang di Pulau Belitung ......................... 33

D. Sistem Mata Pencaharian Penduduk Pulau Belitung ......................... 35

E. Sistem Sosial di Pulau Belitung ..................................................... 41

F. Urang Laut/Sekak, Urang Darat, dan Campuran ............................. 47 
G. Sistem Kekerabatan

H. Potensi Kesenian

BAB III TARI GAJA MENUNGGANG: ANALISIS TANDA

DAN MAKNA

A. Analisis Teks Tari Gaja Menunggang

1. Koreografi tari Gaja Menunggang

a. Aspek gerak tari Gaja Menunggang .

b. Aspek penari dalam tari Gaja Menunggang ................................. 79

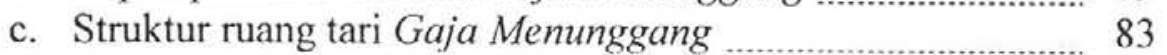

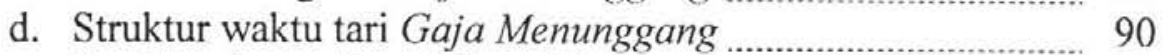

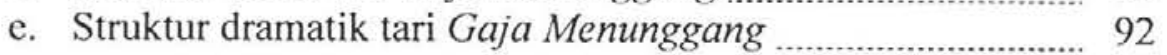

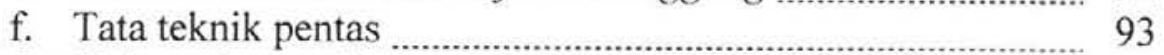

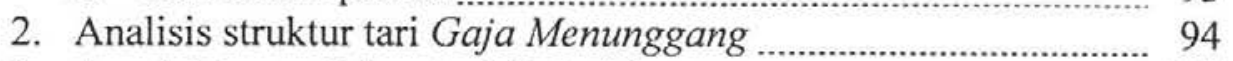

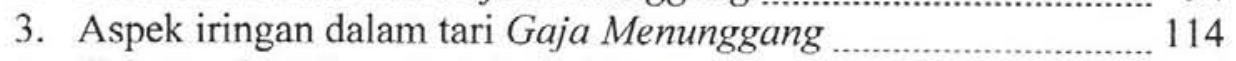

B. Analisis Tanda Dalam Tari Gaja Menunggang ..................................... 123

1. Identifikasi dan penafsiran tanda-tanda dalam gerak tari Gaja Menunggang

2. Identifikasi dan penafsiran tanda-tanda dalam musik dan pantun tari Gaja Menunggang

3. Identifikasi dan penafsiran tanda-tanda dalam busana dan tema tari Gaja Menunggang .

C. Tari Gaja Menunggang, Mitos Gaja Mina: Konsep Tanda dan Makna Masyarakat Suku Sawang Belitung

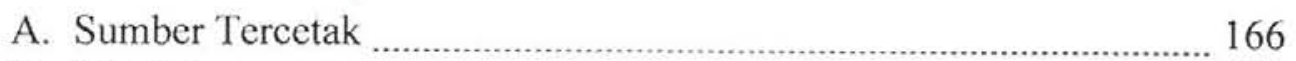

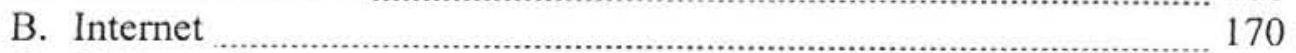

C. Diskografi

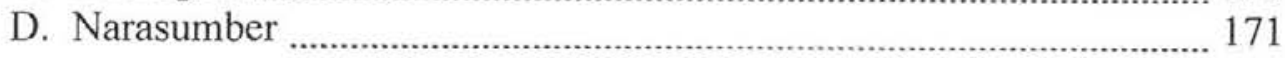

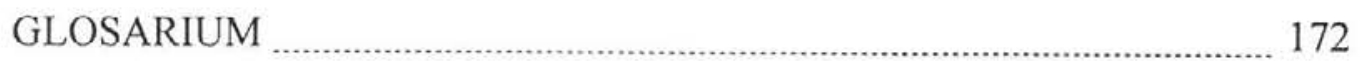




\section{DAFTAR GAMBAR}

Gambar.1. Pulau Belitung, citra satelit skala 1:25.000.000.

Gambar.2. Peta pulau Belitung skala 1:25.000.000.

Gambar.3. Warna merah menunjukkan wilayah administrasi kabupaten Belitung.

Gambar.4. Warna merah menunjukkan wilayah administrasi kabupaten Belitung Timur.

Gambar.5. Peta topografi pulau Belitung skala 1:25.000.000.

Gambar.6. Citra satelit dari kota Tanjungpandan. Sebelah baratnya adalah laut dan selatannya adalah aliran sungai Cerucuk skala 1:500.000.

Gambar.7. Campak Darat, menari sambil berbalas pantun dengan diiringi alat musik Melayu yang sederhana (piul, gendang, dan tawak-tawak).

Gambar.8. Atraksi Beripat, adu ketangkasan bersenjatakan rotan.

Gambar.9. Salah satu adegan dalam teater Dul Mulok.

Gambar.10. Tari Sambut, salah satu dari sekian banyak jenis tari penyambutan tamu yang berkembang di Belitung.

Gambar.11. Barongsai, kesenian sesingaan dari Cina yang sarat dengan atraksi yang menarik.

Gambar.12. Kuda Lumping, sarat mistis dan atraksi kesurupan.

Gambar.13. Barong Bali yang dipentaskan saat

Sail Wakatobi Belitung 2011

di Tanjung Kelayang, Belitung

Gambar.14. Tari Nyusor Tebing, salah satu tari khas suku Sawang.

Gambar.15. Tari Simbang Dale dalam ritual Buang Jong, dilaksanaan bersamaan dengan prosesi Naik Tiang.Jitun.

Gambar.16. Tari Ancak saat ritual Buang Jong.

Gambar.17. Sikap kaki bujang.

Gambar.18. Sikap kaki dare.

Gambar.19. Cara mengenakan kain sebagai busana

penari perempuan untuk tari Gaja Menunggang.
Gambar.20. Cara mengenakan kain sebagai busana utama penari laki-laki untuk tari Gaja Menunggang dulu dan sekarang. Tidak banyak perubahan, selain penambahan baju bila diinginkan.

Gambar.21. Salah satu contoh busana yang dikenakan penari perempuan dalam tari Gaja Menunggang pada masa sekarang.

Gambar.22.Skema dramatika tari Gaja Menunggang.

Gambar.23. Bentuk gimbel (gendang sebelah) yang digunakan untuk mengiringi tari Gaja Menunggang.

Gambar.24. Bagan semiosis motif begulut kolek

Gambar.25. Pola lantai gerak lingkong karang. 
Gambar.26. Pola lantai gerak lingkong karang bedayung bujang

di mana penari perempuan mengitari penari laki-laki.

Gambar.27. Pola lantai gerak lingkong karang bedayung dare

di mana penari laki-laki mengitari penari perempuan.

Gambar.28. Bagan semiosis motif lingkong karang

Gambar.29. Pose gerak tangan bedayung.

Gambar.30. Bagan semiosis sikap duduk penari

Gambar.31. Contoh dari peralatan memancing sederhana.

Gambar.32. Bagan semiosis frase mancing

Gambar.33. Pose gerak mancing yang hanya dilakukan oleh penari laki-laki.

Gambar.34. Pose gerak tangan muja yang hanya dilakukan

oleh penari perempuan.

Gambar.35. Bagan semiosis busana penari

Gambar.36. Bagan semiosis mitos Gaja Mina 


\section{DAFTAR TABEL}

Tabel.1. Perbandingan tempat peribadatan di pulau Belitung. ................... 34

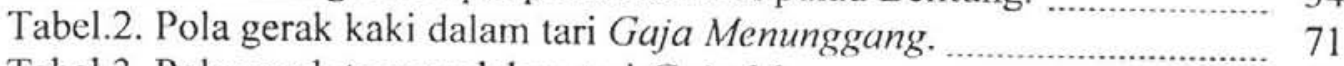

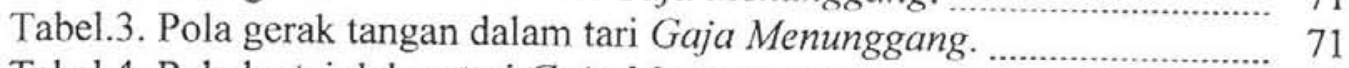

Tabel.4. Pola lantai dalam tari Gaja Menunggang. ……............................. 86

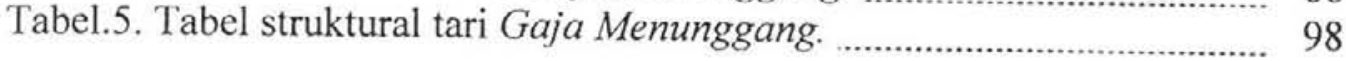




\section{BAB I \\ PENDAHULUAN}

\section{A. Latar Belakang Masalah}

Tari adalah sebuah seni yang sangat kompleks karena tersusun atas banyak unsur seperti gerak, ruang. waktu, musik, busana, dan lain-lain yang menjadikannya sebagai sistem yang membawa informasi beberapa saluran secara simultan. Saluran-saluran ini juga menjadi pembawa informasi atas penandapenanda identitas dari masyarakat pemilik tari itu dan menjadi simbolisasi dari masyarakat tersebut. Simbol-simbol tersebut umumnya dapat dikenali sebagai milik masyarakat tersebut dan memberikan sebuah batasan yang jelas atas identitas mayarakat tersebut.' Ada beberapa pendapat dan teori tentang simbol, namun ada dua pendapat utama yang dipelopori oleh Ferdinand de Sausurre dengan konsep "penanda-petanda"nya dan istilah semiologi, serta Charles Sanders Peirce dengan konsep triadiknya dan istilah semiotika. Perbedaan antara dua ahli ilmu tanda ini terletak pada hubungan antara penanda (ikon) dan petanda (indeks). Bagi Sausurre, hubungan antara keduanya bersifat abritrer (semena-mena/bebas) atau tidak bermotif. Namun bagi Peirce, hubungan antara indeks dan ikon bersifat alamiah, dan representasi ikon jelas-jelas memiliki motif. ${ }^{2}$ Jadi, bagi Saussure interpretasi sebuah tanda atau penandaan atas sesuatu cenderung semena-mena dan hubungan antara petanda dengan penandanya cenderung tidak bersifat

\footnotetext{
${ }^{1}$ Anya Peterson Royce, 2007, Antropologi Tari, terj. F. X. Widaryanto, Bandung: Sunan Ambu Press, pp. 170-177.

${ }^{2}$ Arthur Asa Berger, 2010, Pengantar Semiotika: Tanda-Tanda dalam Kebudayaan Kontemporer, terj. M Dwi Marianto, Yogyakarta: Tiara Wacana, pp. 13-25.
} 
alamiah. Sebaliknya bagi Peirce, hubungan antara keduanya sesungguhnya memiliki suatu maksud dan tujuan tertentu, seperti harapan, doa, atau juga nilainilai tertentu.

Konsep tari atau kesenian yang menjadi channel atas simbol-simbol dalam masyarakat ini memiliki banyak contoh, salah satunya adalah masyarakat suku Sawang yang ada di pulau Belitung. Suku Sawang sendiri adalah satu dari sekian banyak penghuni pulau Belitung, bersama dengan suku Melayu, Cina, Bugis, Jawa, Bali, dan suku-suku lainnya. Kesenian adalah salah satu identitas yang dimiliki oleh suku-suku tersebut, yang membedakan satu suku dengan suku yang lainnya selain kondisi fisik individu yang sangat sulit dipakai sebagai alat pengklasifikasian. Keberadaan banyak suku dengan beragam kesenian ini tentu saja menambah keragaman budaya pulau Belitung, karena masing-masing etnis memiliki ciri khasnya masing-masing. Salah satu keragaman budaya yang ada di pulau Belitung tentu saja suku Sawang Belitung, dengan ciri khasnya sebagai suku yang pernah hidup nomaden mengembara di laut.

Suku Sawang Belitung adalah suku pengembara laut dan merupakan suku asli pulau Belitung. Mereka adalah orang-orang nomaden yang hidup di atas perahu dan mengembara di kawasan perairan di wilayah Bangka dan terutama Belitung. Mereka biasanya hidup dalam kelompok kecil di mana satu perahu ditempati oleh satu keluarga yang terdiri 5-6 orang anggota keluarga. Mereka adalah pelaut, perenang, dan penyelam yang handal, yang membuat perahunya sendiri serta melengkapinya dengan alat-alat menangkap ikan sederhana seperti panah, 
tombak, dan belakangan juga dengan pancing dan jala. Mereka mencukupi kebutuhan hidup sehari-harinya dari laut, baik untuk dikonsumsi sendiri, maupun untuk dipertukarkan dengan kebutuhan lain seperti beras, gula, kacang-kacangan, dan sebagainya. ${ }^{3}$

Masyarakat suku Sawang adalah penganut paham Animisme-Shamanisme, yaitu kepercayaan atas roh-roh atau makhluk halus yang ada di alam, di mana dukun atau shaman adalah mediator atau penghubung antara dunia manusia dengan alam gaib. ${ }^{4}$ Orang suku Sawang memiliki kepercayaan terhadap roh dan mahluk halus yang menguasai tempat-tempat tertentu yang memiliki peran ganda; bisa baik ataupun jahat, dan mempengaruhi alur hidup manusia. Selain itu, mereka juga percaya akan benda-benda tertentu yang memiliki kekuatan gaib yang bisa digunakan sebagai sarana tertentu ataupun jimat. Dukun sendiri adalah orang yang menjadi mediator antara dunia manusia dengan dunia gaib, yang memiliki kekuatan gaib tertentu yang bisa digunakan untuk berbagai tujuan yang baik maupun jahat. Dukun dalam masyarakat suku Sawang merupakan posisi yang bisa disandang oleh siapa saja yang mau dan mampu, tidak terbatas oleh jenis kelamin atau pertalian darah. ${ }^{5}$

Kesenian yang dikenal oleh masyarakat suku Sawang terbatas pada beberapa jenis saja, terutama seni pertunjukan seperti musik dan tari serta seni sastra lisan seperti pantun. Kesenian yang berkembang dalam masyarakat suku Sawang

\footnotetext{
${ }^{3}$ Salim Y.A.H., 2009, "Suku Sawang Belitung dan Muang Jong", dalam Warta Praja, edisi 07, Juli 2009 , p. 12.

${ }^{4}$ http://id.wikipedia.org/wiki/Animisme.

${ }^{5}$ Salim Y.A.H., op. cit., pp. 14-15.
} 
biasanya adalah perpaduan antara seni pantun dengan seni musik, atau antara musik, pantun, dan tari. Seni pertunjukan milik masyarakat suku Sawang yang paling utama adalah Buang Jong, sebuah seni ritual yang di dalamnya terdapat banyak jenis-jenis seni pertunjukan seperti tari Simbang Dale, tari Ancak, dan sebagainya. Selain itu dikenal juga Beluncong, nyanyian berbalas pantun yang digunakan sebagai media untuk mengenang seseorang yang baru saja meninggal. Pantun yang dibawakan bersifat bebas, dan sebagian besar berisikan riwayat hidup ataupun kebaikan yang pernah dilakukan oleh orang yang telah meninggal tersebut. ${ }^{6}$ Satu hal lagi yang perlu diingat tentang pantun dan syair lagu masyarakat suku Sawang adalah mereka tidak pernah digunakan untuk mencela atau menjelek-jelekkan orang. ${ }^{\text {? }}$

Selain yang telah disebutkan di atas, masyarakat suku Sawang juga mengenal beberapa jenis tari dan lagu yang lainnya, salah satunya adalah tari Gaja Menunggang. Keberadaan tari Gaja Menunggang tidak bisa dilepaskan dari cerita atau mitos tentang Gaja Mina dan masyarakat suku Sawang sebagai teks yang lebih besar yang keberadaannya melingkupi tari Gaja Menunggang. Mitos Gaja Mina yang dipercayai keberadaannya oleh masyarakat suku Sawang bisa dikatakan sebagai bentuk legitimasi hubungan antara suku Sawang dengan laut itu sendiri, serta sebagai sebuah gambaran identitas mereka sebagai orang yang berbudaya maritim dan juga berkaitan dengan sistem kepercayaan mereka.

\footnotetext{
${ }^{6}$ Asin Bahari, 1987, Mengenal Kehidupan Adat Istiadat Suku Laut (Sawang) di Pulau Belitung, Tanjungpandan: Dinas Pariwisata Kabupaten Daerah Tingkat II Belitung, pp. 10-15.

${ }^{7}$ Wawancara dengan Idris Said, 31 Juli 2011.
} 
Gaja Mina sendiri merupakan hewan mitos atau kriptid yang keberadaannya dipercayai oleh suku-suku Laut yang ada di Kepulauan Riau, Bangka, dan termasuk juga suku Sawang Belitung. Hewan ini biasa disebut dengan panggilan trunko, yang keberadaannya dalam berbagai bidang ilmu sangat diragukan. Trunko ini digambarkan sebagai hewan laut besar dengan bulu putih dan berbelalai yang menyambung langsung ke torsonya. Walaupun demikian, kemunculan trunko yang terekspos oleh media ini kemudian dipahami sebagai sebuah globster, yakni suatu gumpalan raksasa, dengan lapisan lemak mengandung kolagen yang kadangkala tersisa saat seekor paus mati sedangkan tengkorak dan kerangkanya terpisah dari kulit dan tenggelam ke dasar laut. ${ }^{8}$

Terlepas dari keberadaan Gaja Mina atau Trunko ini sebagai sebuah kebenaran atau hanya sekedar sebuah cerita saja, namun masyarakat suku Sawang memiliki budaya dan kepercayaannya sendiri atas keberadaan Gaja Mina ini sebagai makhluk halus penguasa laut, satu dari sekian banyak penguasa laut dalam kepercayaan mercka. Adapun cerita tentang Gaja Mina yang menjadi latar belakang tari Gaja Menunggang ini adalah sebagai berikut :

"Dulu, masyarakat Suku Sawang memiliki kebiasaan untuk menombak dan memancing ikan di tengah laut maupun di pinggir pulau-pulau kecil pada malam bulan purnama. Pada waktu itu mereka melihat binatang laut yang sangat besar dan menakutkan. Keberadaan binatang tersebut membuat mereka ketakutan sehingga dengan segera mereka merapat ke pantai. Keberadaan binatang tersebut kemudian mereka laporkan kepada dukun. Dukun tersebut berkata bahwa makhluk yang mereka lihat tersebut bernama Gaja Menunggang atau Gaja Mina yang memang biasa naik ke pantai-pantai untuk mencari makanan berupa buah pandan laut pada malam bulan purnama.

\footnotetext{
${ }^{8}$ http://id.wikipedia.org/wiki/Trunko
} 
Beberapa lama setelah kejadian tersebut, terjadi peristiwa ganjil lain berupa raibnya scorang pemuda Suku Sawang yang gagah dan sakti mandraguna tanpa meninggalkan satupun jejak. Malam harinya, dukun mendapatkan pesan bahwa si pemuda tersebut telah berpindah alam dengan tujuan menjaga Gaja Mina agar tidak mengganggu dan menakuti masyarakat Suku Sawang yang mencari nafkah di laut. Pemuda tersebut tidak boleh disebutkan namanya sama sekali." 9

Perihal pelarangan penyebutan nama tersebut, hampir semua dewa-dewi dalam kepercayaan suku Sawang tidak boleh disebutkan namanya kecuali pada saat-saat tertentu seperti upacara Buang Jong. Hal tersebut dikarenakan si pemilik nama akan "terpanggil" dan datang untuk menemui yang telah menyebut namanya. Masyarakat suku Sawang percaya, apabila dewa-dewi tersebut dipanggil dan datang pada saat yang tidak tepat, maka sesuatu yang buruk dapat menimpa mereka. Salah satu efek negatif yang mereka takuti atas kedatangan para dewa-dewi yang tidak pada waktunya tersebut adalah tersebarnya penyakit yang mereka sebut sebagai penyakit sampar.

Tari Gaja Menunggang adalah tari yang bersifat sekuler yang berarti tari ini tidak memiliki hubungan dengan ritual. Walaupun tari ini biasa ditampilkan saat ritual Buang Jong, namun fungsinya terbatas hanya sebagai hiburan saja. Selain saat ritual Buang Jong, tari ini bisa dipentaskan kapan saja. Tempat pentas dari tari Gaja Menunggang ini cenderung di tempat terbuka seperti tanah lapang ataupun panggung terbuka.

Keberadaan simbol-simbol dalam tari sebagai identitas masyarakat pendukungnya tersebut juga terdapat dalam tari Gaja Menunggang, sebuah tari tradisi masyarakat suku Sawang Belitung. Tari Gaja Menunggang merupakan tari

\footnotetext{
${ }^{9}$ Dokumentasi Kesenian Tradisional Kabupaten Belitung, teks berjalan dalam video, 2005.
} 
yang tergolong sekuler, walaupun cerita yang melatarbelakangi tari ini sangat berkaitan dengan kepercayaan dari masyarakat suku Sawang. Sebagai tari tradisi yang hidup dan berkembang di lingkungan masyarakat primordial, keberadaan simbol-simbol presentasional di dalam tari Gaja Menunggang ini tidak lagi berada pada kisaran indah dan menyenangkan, melainkan sebagai suatu pernyataan atas kepercayaan, makna, dan nilai yang berlaku dalam lingkungan masyarakat tersebut serta berkaitan dengan sesuatu yang transenden. ${ }^{10}$ Singkatnya, simbol yang ada dalam tari Gaja Menunggang merupakan penandaan atas sesuatu yang berada di luar wujud simbol itu sendiri; yang keberadaannya melibatkan tiga unsur yaitu simbol itu sendiri, satu atau lebih rujukan, dan hubungan antara simbol dengan rujukan itu sendiri. ${ }^{\prime \prime}$

Tari Gaja Menunggang, sebagai hasil budaya masyarakat Suku Sawang mengandung banyak sekali nilai-nilai. Nilai-nilai tersebut tidak hanya berkaitan dengan sistem kepercayaan masyarakat Suku Sawang, tetapi juga berkaitan dengan sejarah awal keberadaan mereka serta menjadi penanda identitas mereka sebagai Suku yang ber-ibu-kan laut. Sayang sekali, kemajuan zaman dan globalisasi membuat keadaan menjadi sulit bagi eksistensi masyarakat suku Sawang. Dimulai dengan usaha untuk membuat pemukiman tetap sebanyak dua kali, yang pertama tahun 1970 bertempat di Kampung Laut, dan yang kedua pada tahun 1985 bertempat di Desa Juru Seberang. ${ }^{12}$ Pengaruh Islam yang lebih dikenal sebagai agama Melayu sedikit banyak mempengaruhi. Masyarakat suku Sawang

\footnotetext{
${ }^{10}$ Jakob Sumardjo, 2006, Estetika Paradoks, Bandung: Sunan Ambu Press, pp 43-47.

${ }^{11}$ Alex Sobur, 2004, Semiotika Komunikasi, Bandung: Remaja Rosdakarya, pp. 155-157.

${ }^{12} \mathrm{http} / / /$ ahok.org/tentang-ahok/di-luar-panggung-timah-konsolidasi-demokrasi-bangka-belitung-5/
} 
sekarang kebanyakan tidak mau lagi disebut sebagai suku Sawang, melainkan sebagai orang Melayu dikarenakan ke-Islam-an mereka. ${ }^{13}$ Hal inilah yang paling mengganggu, ketika orang suku Sawang sendiri tidak mau lagi mengakui identitas asli mereka sebagai Orang Laut.

\section{B. Rumusan Masalah}

Berdasarkan latar belakang masalah yang telah diungkap di atas, maka rumusan masalah yang ada yaitu:

1. Bagaimana bentuk teks tari Gaja Menunggang?

2. Bagaimana makna simbol-simbol yang terdapat dalam tari Gaja Menunggang?

\section{Tujuan Penelitian}

Berdasarkan latar belakang dan rumusan masalah yang diungkapkan di atas, maka tujuan dari penelitian ini adalah :

1. Mendeskripsikan tentang bentuk teks dari tari Gaja Menunggang, menggunakan pemahaman-pemahaman yang lebih global tanpa mengubah esensi dari teks tari itu sendiri.

2. Menganalisis makna-makna atas simbol yang terdapat dalam tari Gaja Menunggang untuk memahami relasi antara masyarakat suku Sawang

\footnotetext{
${ }^{13}$ Salim Y.A.H., 2009, op. cit., p.15.
} 
dan laut, yang terekam di dalam tari Ciaja Menunggang dan mitos Gaja Mina.

\section{Manfaat Penelitian}

Adapun manfaat yang diharapkan dari penclitian ini adalah:

1. Mengupas teks tari Gaja Menunggang untuk mengenal lebih jauh tentang suku Sawang sebagai salah satu keragaman budaya yang dimiliki oleh pulau Belitung dan Indonesia.

2. Memperkenalkan tari Gaja Menunggang sebagai salah satu local genius yang ada di Belitung.

\section{E. Tinjauan Sumber}

Sumber-sumber yang menjadi tinjauan secara spesifik antara lain:

Buku yang bercerita tentang masyarakat suku Sawang adalah tulisan Asin Bahari pada tahun 1987 dengan judul Mengenal Kehidupan Adat Istiadat Suku Laut (Sawang) di Pulau Belitung. Buku ini memberikan sebuah pemahaman tentang sebagian cara hidup suku Sawang. Buku ini sangat membantu dalam hal mengenal masyarakat suku Sawang, karena masyarakat suku Sawang dulu dan sekarang tidak terlalu memiliki banyak perubahan dari segi pola pikir.

Tulisan lain yang tentang masyarakat suku Sawang adalah tulisan Salim Y. A. H. dalam buletin Warta Praja edisi Juli 2009 dengan judul "Suku Sawang Belitung dan Muang Jong". Tulisan ini memberikan sebuah pemahaman 
tambahan tentang suku Sawang yang tidak terdapat dalam buku Asin Bahari, terutama tentang alur sejarah yang telah dilalui oleh masyarakat suku Sawang hingga sekarang serta tentang ritual Buang Jong.

Salah satu sumber acuan untuk mengupas tari Gaja Menunggang dari sisi teks tarinya adalah buku Kajian Tari, Teks dan Konteks (2007) yang ditulis oleh Y. Sumandiyo Iladi. Buku ini digunakan sebagai acuan untuk mendeskripsikan tari Gaja Menunggang dari permasalahan teks tari, untuk mengetahui struktur tari Gaja Menunggang. Sebagai tambahan, tulisan Ben Suharto dalam Jurnal MMI Seni Pertunjukan Indonesia tahun II no 21991 dengan judul "Pengamatan Tari Gambyong Melalui Pendekatan Berlapis Ganda" halaman 164-185 diacu secara khusus terutama untuk membantu mengungkap struktur dari tari Gaja Menunggang. Tulisan Ben Suharto ini menggunakan konsep analisis struktur versi Adrienne Kaepler yang didasarkan kepada analogi linguistik.

Buku yang berkaitan dengan teori simbol adalah buku terjemahan $\mathrm{M}$. Dwi Marianto terbitan Mei 2010 dengan judul Pengantar Semiotika, Tanda-tanda dalam Kebudayaan Kontemporer, Edisi Baru yang diterjemahkan dari buku Arthur Asa Berger dengan judul Signs in Contemporary Culture: An Introduction to Semiotics. Buku ini menjadi salah satu acuan utama untuk mendapatkan pemahaman idesional tentang teori-teori tanda. 
Buku lainnya yang juga berkaitan dengan teori simbol adalah Semiotika Komunikasi yang ditulis oleh Alex Sobur. Buku ini memberikan pemahaman tentang teori simbol, serta tentang apa itu simbol dan makna. Walaupun buku ini ditujukan untuk bidang linguistik (bahasa), namun isi buku ini masih bisa diaplikasikan dibidang tari dengan cara membuat sebuah analogi antara bahasa dan tari sebagai suatu sistem simbol.

Buku ketiga yang melengkapi pemahaman tentang teori tanda adalah Semiotika Visual, Konsep, Isu, dan Problem Ikonisitas (2011) tulisan Kris Budiman yang merupakan kompilasi dari 3 buku yang terbit sebelumnya, yaitu Semiotika Visual (2004), Ikonisilas, Semiotika Sastra dan Seni Visual (2005), serta Kosa Semiotika (1999). Buku ini hampir sama dengan kedua buku sebelumnya, dengan bahasan berupa teori-teori yang berkembang dalam dunia semiotika. Namun ada beberapa poin yang tidak ada dalam buku sebelumnya yang tertuang dalam buku ini secara jelas. Kelebihan lain dari buku ini adalah adanya pemberian contoh berupa gambar dan semacamnya, yang membuat apa yang diterangkan lebih mudah untuk dicerna.

\section{F. Pendekatan Penelitian}

Pendekatan penelitian yang digunakan dalam penelitian ini adalah analisis semiotika Charles Sanders Peirce. Perlu diketahui bahwa dalam analisis semiotika dikenal dua teori besar, yaitu teori Charles Sanders Peirce dan teori Ferdinand de Saussure. Peirce dikenal dengan konsep triadiknya, di mana tanda selalu berkaitan 
dengan objek dan interpretantnya. ${ }^{14}$ Saussure sendiri berpendapat bahwa tanda adalah kesatuan dari suatu bentuk penanda dengan sebuah ide atau petanda. ${ }^{15}$ Perbedaan antara dua ahli ilmu tanda ini terletak pada hubungan antara penanda (objek) dan petanda (interpretant). Bagi Sausurre, hubungan antara keduanya bersifat abritrer (semena-mena/bebas) atau tidak bermotif. Namun bagi Peirce, hubungan antara objek dan interpretant bersifat alamiah, dan representasi ikon jelas-jelas memiliki motif. $^{16}$

Dalam semiotika sosial, diketahui ada dua tahap yang harus dilakukan, yaitu tahap heuristik (first order semiotics) dan tahap hermenetik (second order semiotics). Tahap heuristik adalah tahap pengamatan terhadap teks tari Gaja Menunggang untuk melihat bentlik dan struktur material dari tari tersebut. Tahap hermenetik sendiri merupakan pemaknaan teks tari secara interpretatif dan intertekstual untuk mendapatkan sebuah signifikansi atau pemaknaan atas makna.

\section{Tari Gaja Menunggang, first order semiotics}

Sebagai sistem tanda tingkat pertama, tari Gaja Menunggang dibedah secara heuristik untuk mengetahui bentuk dan struktur dari tari Gaja Menunggang itu sendiri. Memang diperlukan beberapa perangkat analisis untuk bisa menghasilkan arti tingkat pertama, berupa pemahaman tentang bentuk dan struktur.

\footnotetext{
${ }_{15}^{14}$ Alex Sobur, 2004, op. cit., pp. 39-42.

${ }^{15}$ Ibid., p. 46.

${ }^{16}$ Arthur Asa Berger, 2010, loc. cit.
} 
Perangkat analisis yang pertama adalah analisis koreografi. Sesuai namanya, analisis ini digunakan untuk mengupas koreografi dari tari Gaja Menunggang seperti gerak, musik, penari, dan aspek-aspek lainnya.

Perangkat analisis yang kedua adalah analisis struktural milik Adrienne Kaeppler yang didasarkan pada analogi linguistik. Kaeppler membagi tari menjadi unit-unit analisis. Unit paling kecil adalah kinem, kemudian dilanjutkan oleh morfokinem (dalam tulisan ini adalah frase gerak), dan unit yang ketiga adalah motif. ${ }^{17}$ Unit-unit pada tingkat selanjutnya adalah frase, kalimat, dan gugus. Satu hal yang membedakan analisis Kaeppler dengan analisis struktur yang lainnya adalah analisis emik, di mana Kaeppler menyinggung masalah gerak dari kategori penutur asli. ${ }^{18}$

Analisis musik tari Gaja Menunggang sendiri menggunakan konsep yang ditawarkan oleh I Wayan Senen dalam menentukan fungsi dan jenis dari musik tari, dan juga konsep dari Pia Gilbert dan Aileene Lockhart tentang elemen musik tari. Gilbert dan Lockhart mengatakan bahwa elemen dari musik pengiring tari terdiri dari ritme, melodi, harmoni, dinamika, tempo, timbre nada, dan bentuk. ${ }^{19}$ Pembagian elemen oleh Gilbert dan Lockhart ini memang lebih banyak dan lengkap dibandingkan pengkategorian yang dilakukan oleh beberapa ahli lainnya. I Wayan Senen sendiri membagi musik tari menjadi 4 jenis berdasarkan fungsinya, yang terdiri dari pengikat tari, pengiring tari, partner tari, dan ilustrasi

\footnotetext{
${ }_{18}^{17}$ Anya Peterson Royce, 2007, op. cit., pp. 72-73.

${ }^{18}$ Ibid., p. 72.

${ }^{19}$ I Wayan Senen, 1983, Pengetahuan Musik Tari Sebuah Pengantar, Yogyakarta: ASTI
Yogyakarta, p. 7.
} 
tari. $^{20}$ Pembagian tersebut didasarkan kepada fungsi dan keterkaitan antara tari dengan musik pengiringnya. Senen juga membagi musik tari berdasarkan bentuk penampilannya menjadi 3 jenis, yaitu musik tari tradisi klasik, musik tari tradisi kerakyatan, dan musik tari kreasi baru. ${ }^{21}$

\section{Tari Gaja Menunggang, second order semiotics}

Seperti yang telah diungkapkan sebelumnya, tahap ini merupakan pemaknaan secara interpretatif dan interteksual. Pemaknaan secara interpretatif atas teks tari Gaja Menunggang bukan sekedar interpretasi yang semena-mena, melainkan interpretasi yang mempertimbangkan konteks sosial dan budaya dari masyarakat suku Sawang Belitung sebagai masyarakat pendukung dari tari Gaja Menunggang ini. Adapun pemaknaan secara intertekstual bertujuan untuk menemukan latar belakang penciptaan teks dan hubungan antar teks tari Gaja Menunggang.

Peirce mengungkapkan bahwa tanda adalah something which stands to somebody for something in some respect or capacity (sesuatu yang hadir/ada untuk seseorang dalam beberapa hal/perhatian atau kapasitas/muatan/isian). ${ }^{22}$ Tanda dalam pemahaman Peirce adalah sesuatu yang mewakili sesuatu untuk seseorang. Sesuatu yang pertama adalah tanda itu sendiri, sesuatu yang kedua adalah objek yang mewakili keberadaan tanda, dan seseorang adalah interpretant yang bisa berarti peneliti maupun masyarakat pendukung. Kehadiran tanda

\footnotetext{
${ }^{20}$ Ibid., pp. 2-4.

${ }^{21}$ Ibid., pp. 29-33.

${ }^{22}$ Alex Sobur, 2004, op. cit., p. 41.
} 
tersebut memiliki kapasitas tertentu, yang berarti keberadaan tanda dan objek tidak secara serta merta atau semena-mena, melainkan memiliki tujuan tertentu.

Konsep semiotika Peirce dikenal sebagai konsep triadik atau signifikasi (signification). Penyebutan tersebut bukan sekedar karena hubungan segitiga antara ground (tanda), interpretant (interpretan), dan referent (objek/acuan). Berdasarkan ground-nya sebagai Kepertamaan, tanda terbagi menjadi sinsign, qualisign, dan legisign. Berdasarkan referent-nya sebagai Kekeduaan, tanda terbagi menjadi indeks, icon, dan symbol. Berdasarkan reference-nya sebagai Keketigaan, tanda terbagi menjadi rhemes, argument, dan dicent sign atau dicisign. $^{23}$

Ciri lain dari teori milik Peirce adalah adanya proses semiosis tak berkesudahan atau oleh Eco dan Derrida disebutkan sebagai unlimited semiosis (semiosis tanpa batas). ${ }^{24}$ Proses ini baru akan berhenti apabila kemampuan untuk menginterpretasi sudah mencapai batas. Dalam proses ini, interpretasi dari proses sebelumnya akan menjadi ground pada proses semiosis tahap selanjutnya, dan seterusnya seperti itu. Hal tersebut ditunjukkan seperti bagan di bawah ini.

${ }^{23}$ Ibid., pp. 40-43.

${ }^{24}$ Kris Budiman, 2011, Semiotika Visual, Konsep, Isu, dan Problem Ikonisitas, Yogyakarta: Jalasutra, pp. 17-18. 


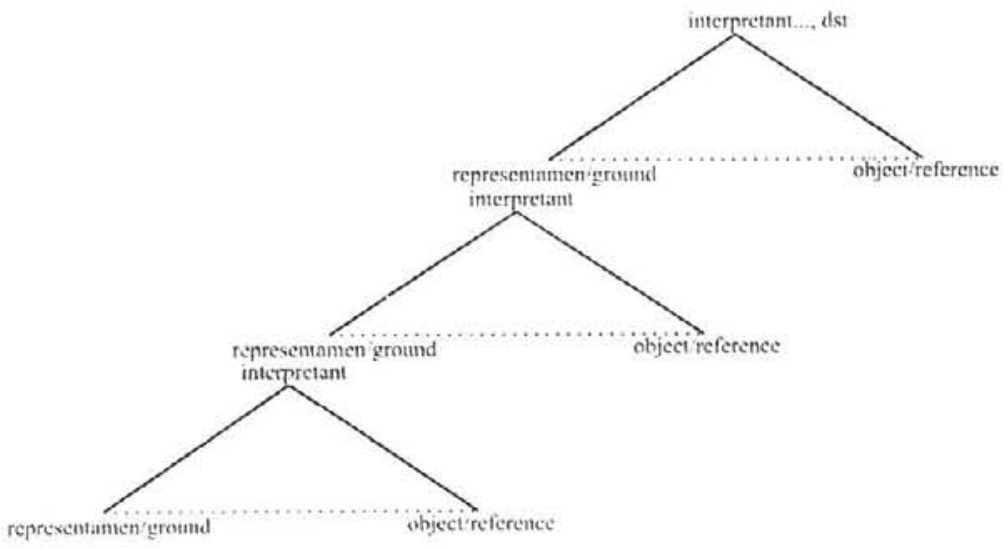

Dillistone sendiri mengungkapkan bahwa simbol adalah sesuatu yang acuannya bukan sekedar konsep belaka, melainkan ada sesuatu yang transenden, sesuatu yang lebih besar, tertinggi, absolut, realitas, cita-cita, nilai, prestasi, masyarakat, kepercayaan, lembaga, dan suatu keadaan tertentu yang menyelubunginya. $^{25}$

Selain itu, Jakob Sumardjo juga mengutarakan pendapat sebagai berikut:

"....Tetapi dalam budaya pra-modern Indonesia, simbol bukan hanya sekedar "tanda tangan" tapi "imanensi Allah" itu sendiri. Simbol dalam seni pra-modern Indonesia adalah tanda kehadiran yang transenden. Acuan simbol buka konotasi gagasan (rasio), dan pengalaman manusia (rasa), akan tetapi hadirnya daya-daya (power) atau energi adikodrati. Simbol adalah tanda kehadiran "yang absolut" itu.

Inilah sebabnya simbol-simbol presentasional Indonesia tidak memperdulikan benda seni itu "indah" atau "menyenangkan", tapi berguna dalam praksis menghadirkan yang transenden tadi itu. Yang dimaksud adalah daya-daya transendennya yang supranatural, yang tidak alami, yang lain dari biasa. Sebilah keris tidak perlu "cantik" tetapi "berisi". Yang berisi adalah yang mengandung daya-daya gaib transenden tadi. Sebilah keris yang cantik, tapi kurang berisi akan dikesampingkan, kalau terdapat sebilah keris lain yang jelek namun penuh daya isi.

Begitulah kita harus menghadapi benda-benda seni pra-modern Indonesia. Ini tidak berarti bahwa simbol seni Indonesia tidak mengacu kepada gagasan atau konsep dan pengalaman, justru simbol-simbol yang mengandung daya transenden tersebut bertolak dari gagasan rasionalnya. Simbol seni pra-modern

${ }^{25}$ F. W. Dillistone, 2006, The Power of Symbols, terjemahan A. Widyamarta, cetakan ke-5, Yogyakarta: Kanisius, pp. 19-20. 
Indonesia dapat dibaca secara modern, yakni adanya konsep besar yang ada di balik simbol, adanya pengalaman seni "keindahannya", yang dapat dibaca secara sistem kepercayaan pra-modern suku, yakni simbol kehadiran yang transenden. Jangan heran apabila artefak-artefak seni pra-modern ini sering dianggap sebagai "pusaka", "jimat", "bertuah", dsb....,26

Jakob Sumardjo dengan jelas menyebutkan tentang simbol-simbol yang terdapat dalam artefak budaya masyarakat primordial Indonesia. Semua karya primordial memang tidak mementingkan persoalan keindahan dalam sebuah pertunjukan, melainkan lebih cederung pada penyampaian atas sesuatu yang lain, sesuatu yang sifatnya transenden. Jakob juga mengungkapkan bahwa untuk mengupas sebuah seni primordial, karya-karya tersebut harus ditempatkan dalam cara berpikir budayanya. ${ }^{27}$ Namun demikian, simbol-simbol tersebut sifatnya kolektif kepercayaan satu budaya, dan tidak bisa dibaca secara universal. Mircea Eliade bahkan mengungkapkan bahwa simbol merupakan bahasa yang ekslusif dipahami oleh semua anggota komunitas saja, dan bagi orang di luar komunitas tersebut simbol-simbol tersebut cenderung tidak bermakna sama sekali. ${ }^{28}$

\section{G. Metode Penelitian}

Secara umum, penelitian yang dilakukan adalah jenis penelitian kualitatif. Jenis penelitian ini dipilih karena penelitian yang akan dilakukan adalah penelitian yang memiliki sifat realitas ganda, holistik, dinamis dengan hasil konstruksi dan

\footnotetext{
${ }^{26}$ Jakob Sumardjo, 2006, op. cit., pp. 44-45.

${ }^{27}$ Ibid., p. 13.

${ }^{28}$ Ibid., pp. 46-47.
} 
pemahaman, dan bukan penelitian dengan pengklasifikasian yang jelas, konkrit, teramati, dan dapat diukur. ${ }^{29}$

\section{Objek Penelitian}

Bahan dan materi dalam penelitian ini adalah masyarakat suku Sawang, mitos Gajah Mina, dan tari Gaja Menunggang. Materi-materi tersebut diolah menggunakan "pisau analisis" semiotika yaitu teori Charles Sanders Peirce di mana di balik makna sebuah tanda pasti terdapat maksud, untuk mendapatkan hasil akhir yang diharapkan berupa hubungan dan apa yang ada di balik tari Gaja Menunggang, mitos Gaja Mina, serta masyarakat suku Sawang.

\section{Instrumen Penelitian}

Sebagai sebuah penelitian yang bersifat kualitatif, tentu saja instrumen utama dari penelitian ini adalah peneliti sendiri untuk melihat, mendengar, mengamati, memproses data secara personal, dan menuliskan laporan penelitian. Namun tentu saja semua itu tidak terlepas dari bantuan instrumen pendukung berupa narasumber, serta alat-alat seperti notehook atau komputer untuk mengetik laporan, alat-alat perekam seperti handycam dan kamera, alat tulis, alat transportasi, dan instrumen lain yang mendukung selama di lapangan.

${ }^{29}$ Sugiyono, 2010, Metode Penelitian Kuantitatif, Kualitatif, dan R\&D, Bandung, Penerbit Alfabeta, p. 110. 


\section{Teknik Pengumpulan Data}

Teknik pengumpulan data dalam penelitian ini adalah gabungan dari :

\section{a. Studi Pustaka}

Studi pustaka dilakukan dengan mencari dan membaca buku yang memiliki kesesuaian dalam hal objek maupun teori yang dipakai dalam penelitian ini. Buku tentang analisis teks, analisis koreografi, adat istiadat masyarakat suku Sawang, suku Laut, dan tentu saja buku-buku tentang semiotika.

\section{b. Observasi}

Observasi dilakukan di lingkungan pemukiman suku Sawang yang terdapat di pulau Belitung dan sekitarnya, terutama di daerah kampung Laut, desa Paal Satu, Jalan Baru, Tanjungpandan, Belitung. Selain itu, kesempatan untuk menyaksikan pertunjukan tari Gaja Menunggang secara langsung didapat pada bulan Juli 2011 tepatnya di pantai wisata Tanjung Pendam, Tanjungpandan, Belitung.

Selain yang telah disebutkan di atas, observasi yang paling nyata telah dilakukan selama belasan tahun. Terlahir sebagai anak dari seorang nelayan membuat kehidupan sehari-hari dekat dengan kebiasaan ayah. Walaupun tidak pernah benar-benar terlibat langsung untuk pergi memancing, namun kebiasaan mengamati kegiatan ayah sebagai nelayan, seperti mempersiapkan perlengkapan, dan bahkan mengantarkan untuk pergi melaut memberikan banyak pemahaman tentang cara hidup melaut dan pola-pola pikir masyarakat yang menggantungkan hidupnya dari hasil laut. 


\section{c. Wawancara}

Wawancara dilakukan terhadap orang-orang yang dianggap memiliki kompetensi mengenai objek penelitian ini seperti para budayawan, tetua suku, dan para pelaku atau penari Gaja Menunggang. Dua orang yang terpilih sebagai narasumber adalah Bapak Idris Said, tetua adat suku Sawang di Jalan Baru dan Bapak Salim Y.A.H, seorang budayawan di Belitung yang memfokuskan perhatiannya pada masyarakat suku Sawang dan ritual Buang.Jong. Kedua orang tersebut adalah narasumber utama yang diharapkan dapat memberikan data-data utama yang dapat membantu penelitian ini.

\section{d. Dokumentasi}

Dokumentasi atas tari Gaja Menunggang dilakukan sebagai salah satu tinjauan sumber untuk membedah objek. Dokumentasi ini bisa berupa rekaman video tari, foto-foto dan gambar-gambar, serta catatan-catatan tulisan tangan seperti manuskrip dan sejenisnya. Dokumentasi yang didapat terkait dengan tari Gaja Menunggang ada dua, yang pertama adalah video Dokumentasi Kesenian Tradisional Belitung yang dibuat pada tahun 2005 dan lagu Campak Laut atau Gaja Menunggang yang dirilis oleh Babel Record dengan tahun pembuatan tidak diketahui. Kedua dokumentasi tersebut sangat membantu untuk lebih merincikan lagi teks koreografi tari Gaja Menunggang, sehingga hanya perlu memastikan beberapa hal saja kepada narasumber yang ada. Keberadaan dokumentasi ini tentu saja telah mengalami sebuah proses dan diketahui oleh masyarakat suku Sawang sebagai pemilik budaya. 


\section{Teknik Analisis Data}

Analisis data selama di lapangan yang akan dilakukan adalah analisis etnografi model James Spradley, yang membagi proses analisis menjadi empat tahap :

a. Analisis domain, untuk memperoleh gambaran umum tentang objek penelitian. Analisis ini digunakan untuk mendapatkan domain yang digunakan sebagai pijakan untuk melanjutkan penelitian.

b. Analisis taksonomi, analisis ini digunakan untuk menjabarkan domain yang telah terpilih secara lebih terperinci.

c. Analisis kompensional, analisis ini digunakan untuk mencari ciri spesifik setiap struktur internal objek penelitian.

d. Analisis tema kultural, analisis ini digunakan untuk mencari hubungan antar domain dan hubungan secara menyeluruh.

\section{Teknik Penulisan Laporan Akhir}

Format penulisan untuk laporan akhir dari penelitian ini digunakan jenis deskriptif analisis. Jenis penulisan tersebut diacu karena penelitian ini bukan hanya sebagai media untuk mendeskripsikan objek saja, melainkan untuk menganalisis apa yang telah terdeskripsikan. Adapun struktur penulisan laporan akhir yang digunakan adalah sebagai berikut : 
BAB. I. yaitu bagian pendahuluan yang terdiri dari beberapa subbab, yaitu A. Latar Belakang Masalah, B. Rumusan Masalah, C. Tujuan Penelitian, D. Manfaat Penelitian, E. Tinjauan Sumber, F. Pendekatan Penelitian, dan G. Metode Penelitian.

BAB. II. merupakan bagian yang menceritakan kondisi sosial budaya masyarakat suku Sawang Belitung. Bagian ini terdiri dari beberapa subbab, meliputi A. Keadaan Geografi Pulau Belitung, B. Suku Sawang dalam Sejarah, C. Sistem Religi, D. Sistem Mata Pencaharian, E. Sistem Sosial, F. Sistem Kekerabatan, dan G. Potensi Kesenian.

BAB. III. adalah bagian yang berisikan hasil penelitian berupa pembahasan dan analisis yang meliputi, A. Teks Tari Gaja Menunggang, meliputi 1. Koreografi Tari Gaja Menunggang, 2. Analisis Struktur Tari Gaja Menunggang, dan 3. Aspek Iringan dalam Tari Gaja Menunggang, serta B. Tari Gaja Menunggang, Analisis Tanda dan Makna, meliputi 1. Identifikasi dan Penafsiran Tanda-tanda dalam Tari Gaja Menunggang, dan 2. Tari Gaja Menunggang, Mitos Gaja Mina, Masyarakat Suku Sawang, dan Laut.

BAB. IV. Kesimpulan yang memberikan jawaban singkat atas rumusan masalah 